\title{
GOVERNMENT DEBT AS THE INTEGRAL PORTFOLIO OF ASSETS AND LIABILITIES GENERATED BY DEBT
}

\author{
Aleksandras Vytautas Rutkauskas ${ }^{1}$, Viktorija Stasytyté丶 ${ }^{2}$, Nijolė Maknickiené $\dot{3}^{3}$ \\ Vilnius Gediminas Technical University, Sauletekio al. 11, \\ LT 10223 Vilnius, Lithuania

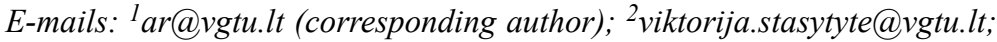 \\ 3nijole.maknickiene@vgtu.lt
}

Received 22 February 2013; accepted 11 June 2013

\begin{abstract}
The paper analyses the possibilities of optimal government (national) debt management, trying to maximize the made-up net value for the debtor with the help of funds borrowed by the government. The integral portfolio of debtor assets and debt service liabilities, based on the borrowed funds, is chosen as a solution for the above-described problem. In the paper, an asset is understood as a position of government expenditures, where funds borrowed by the government are used and create a quantifiable profit (value) or the measurable damage or loss is avoided if funds are borrowed. Actually, liabilities are the main debt service positions. Naturally, the value generated by assets, as well as funds spent to settle the liabilities, could be analytically adequately evaluated only in stochastic dimension. Consequently, multidimensional multicriteria stochastic optimization technique is used as a technical solution to the formulated problem. In analytical decisions, the budget funds borrowed by the government are treated as marginal funds. Taking into account a completely new decision technique that has been invoked for government debt management, the methods of decisions are described quite particularly.
\end{abstract}

Keywords: government debt, integral asset and liability portfolio, debt-generated net value to a borrower, multicriteria stochastic optimization, net present value generated by debt, marginal utility.

Reference to this paper should be made as follows: Rutkauskas, A. V.; Stasytyte, V.; Maknickiene, N. 2014. Government debt as the integral portfolio of assets and liabilities generated by debt, Journal of Business Economics and Management 15(1): 22-40.

JEL Classification: H63, H74, G11, E6.

\section{Introduction}

The adequate investment portfolio was selected to reach the main objective of the paper, namely, to prepare the maximization scheme of net utility for the debtor, generated by government debt, and using the integral portfolio model of asset and liability management to apply the scheme in Lithuanian conditions (Rutkauskas 2006).

In this paper, the debt category is analysed, which as a financial instrument (Landon, Smith 2007; Martin 2009; Pan, Wang 2012) at its basic content formation moment is 
contemporary with money as trade tools' origin; it has invaluable merit in developing division of labour as the most effective all-time economic means. Indeed, the importance and evolution of division of labour problem achieved the key attention of the scientific thought of economics since Plato to Friedrich A. von Hayek (The Concise Encyclopedia of Economics... 2013). Intensive development of the trade, determined by the division of labour necessity (Pridotkiene, Dapkus 2011; Bruneckiene, Paltanaviciene 2012), has been the driver behind the abundance and improvement of financial relations and instruments. The success of the most impressive contemporary phenomenon - globalization - highly depends on the success of division of labour from the territorial as well as technological points of view, and on successful trading efficiency as well as perfection of the attendant system of financial instruments (Stulz 2005; De Santis, Gerard 2006; Mishkin 2007; Pekarskiene, Susniene 2011).

Etymology of debt states that the English word "debt" came from Latin "ebere" (to owe) somewhere in the XVIII century. However, there is no doubt that trading, which transformed 5000 years ago, has been using the idea of trust (credit - trust, creditum - loan) in the sense that it is possible to trust the promise to pay for goods after their delivery. In finance, debt is a means of present use of the purchasing power receivable by the debtor in the future, maybe even far before it has been earned. Some companies and corporations use debt as part of their overall corporate finance strategy (Bradley, Chen 2011; Norvaisiene 2012; Zhan, Zeng 2012).

Although in the act of debt formation the debtor is assumed to be the primary side assuming the risk, however, a debt transaction can take place only under the condition of a possible bilateral benefit (Bruche, Naqvi 2010). In this paper, the main attention will be paid to the borrower (debtor), attempting to not only realize benefit possibilities, but also circumstances applicable for borrowing in situations when a debt increase not only becomes risky but can also become less useful in cases of a big guarantee, which is not only because the debt as such was unsuccessful, but also because of its inadmissible enormous growth that results in the loss of the possibility by a debtor to use it efficiently even under standard borrowing conditions.

The paper reveals the attempts of the authors to ground the management principles of the debt, the emerging of which is marked by the possibilities of uncertainty, when the existence of uncertainty is evident in forming costs of the debt, as well as in creating the value using debt funds.

\section{Debt growth rate and related problems}

As division of labour is the most important economic tool in the international context, the balance of needs and possibilities of all the subjects is a particularly important instrument of economic development management in a particular country. Only properly composed monetary and fiscal policy could foster discussion about the guarantee for sustainable economic growth and the most effective utilization of national disposable resources. (Muscatelli et al. 2004; Kalyuzhnova, Nygaard 2009; Canzoneri et al. 2010; Žvirblis, Buračas 2010; Bartolomeo, Giuli 2011; Asici 2013). 
However, in the paper, the authors confine themselves to the creation of theoretical optimization model of government debt acquisition means and forms of use. Also, the model will be applied experimentally to Lithuanian conditions in order to maximize the utility receivable using government debt, i.e. selecting the traditional international financial institutions as the debt sources, but evaluating the effect of debt use according to the government debt use possibilities established in Lithuania.

Also, it is necessary to carefully evaluate the sufficient created benefit of every debt unit in the future to prevent its total present value (utility) from dropping below the taken amount of the present value of debt. According to statistical data, if government debt equals GDP level, the debt efficiency starts diminishing significantly. Analysts often notice the presence of certain debt thresholds that should not be exceeded.

The reasons for individual and household debts as well as borrowing by a specific business unit are similar: to obtain a highly priced asset for the use before its settlement, or to use a loan in order to gain the purchasing power for implementation of a desired objective. The success of borrowing and debt use is important not only to the above-mentioned entities, but also for the entire country. However, government debts became the permanent focus of attention for analyst and politicians (Drudi, Giordano 2000; Balibek, Koksalan 2010). Government debt management becomes one of the most important national development problems in countries with high and developing level of economy (Qin et al. 2006; Melecky 2012; De Mendonca, Machado 2013). Moreover, failed foreign debt management cases create the environment beneficial for regional or global crises. Although analysts have long been trumpeting that at certain proportions a foreign debt results in the negative effect of debt growth impact on the debtor (Mohd Daud, Podivinsky 2012), still, the world inevitably sinks into the debt-caused non-existence with heavily predictable and controllable results.

\section{Waymarks to national debt management success}

\subsection{Government functions mostly realized using government debt funds}

While performing its purpose, a government must get involved in many fields of state life and social activities, which are at the centre of public attention. Management of the current situation in these fields requires for funds that are possessed by the government in the form of state budget. In Lithuania, the state budget is allocated to the following fields: social security, education, health, economy, business promotion, transport and communication, agriculture, environmental protection, public order and security, defence, leisure, culture and religion (2013 metų...).

The funds borrowed by the government become part of the state budget. Also, borrowed funds are usually used to repay previous debts (for example, repurchase of government securities) and finance the budget deficit. Thus, government debt actually contributes to the financing of all the fields distinguished above. In the paper, however, the authors will analyse only the part of the debt for t-year that is used for t-year budget expenses and investments. 


\subsection{Problems with appraisal of public assets}

Indeed, assets are the basic source of economic vitality and development. In financial accounting, assets are economic resources. It is usually assumed that assets represent value of ownership that can be converted into cash although an asset itself is a resource that can be controlled to bring the utility for its holder.

It is worth noticing that the concept of assets used in the title of the paper differs from the one used in net debt calculation: the net debt is calculated as gross debt minus direct values of financial assets' debt instruments (see Table 1). According to economic conception, an asset is a piece of property, using which an economic benefit may be derived during a certain period of time. Thus, borrower's assets, generated by debt, are the volume of debt directly fallen into one's property.

Table 1. Calculation of net debt

\begin{tabular}{lll}
\hline $\begin{array}{c}\text { Gross debt (gross value of liabilities } \\
\text { in the form of debt means) } \\
\text { a }\end{array}$ & \multicolumn{1}{c}{$\begin{array}{c}\text { Financial assets obtained } \\
\text { using debt means } \\
\mathrm{b}\end{array}$} & $\begin{array}{c}\text { Net debt } \\
\mathrm{C}=\mathrm{a}-\mathrm{b}\end{array}$ \\
\hline $\begin{array}{l}\text { SDRs (Special Drawing Rights) } \\
\text { Currency and deposits }\end{array}$ & $\begin{array}{l}\text { Monetary gold and SDRs } \\
\text { Currency and deposits }\end{array}$ \\
$\begin{array}{l}\text { Debt securities } \\
\text { Loans }\end{array}$ & $\begin{array}{l}\text { Debt securities } \\
\text { Loans }\end{array}$ \\
$\begin{array}{l}\text { Insurance, pension and standardized } \\
\text { guarantee schemes }\end{array}$ & $\begin{array}{l}\text { Insurance, pension and } \\
\text { standardized guarantee schemes } \\
\text { Other accounts payable }\end{array}$ & Other account receivable \\
\hline Total gross debt & $\begin{array}{l}\text { Total financial assets } \\
\text { corresponding to gross debt }\end{array}$ \\
\hline
\end{tabular}

Gross debt evaluation is usually based on the sum of total debt, which consists of liabilities according to all debt instruments. A debt instrument is defined as a financial claim that requires payments of interest and/or principal of the debtor to the creditor at a date, or dates in the future. Financial assets corresponding to debt instruments (column $b$, Table 1) show the way, in which indebted funds reach the debtor accounts. These accounts serve for the debtor to use the economic funds.

\section{Debt optimization. What is it?}

\subsection{Peculiarities of debt optimization}

While analysing debt management, scientific literature mainly focuses on cost of debt minimization (Lim 2011; Chen 2012). In case of every country, cost ambiguity, different debt service plans appropriate for both debt sides - the creditor and the debtor - as well as uncertainty, which accompanies all debt service process, points out the importance of debt service cost minimization. However, emphasis on the mentioned aspects alone does not consider the reasons behind borrowing and the ways debt utility success or failure could also influence the effect generated by debt. 
If types of borrowing would automatically suggest the efficiency of debt, such problemsolving of debt management as well as debt optimization could be reasoned. But real estate debt bubbles have shown that activity absorbing the borrowed funds has caused these uncertainties, which to the great extent contributed to the continuing world economic crisis (Dubinskas, Stunguriene 2010; Afonso, Jalles 2013).

Since any business associates its development possibilities with borrowing possibilities, debt analysis will not be complete without combining debt objectives and cost of debt possibilities. Certainly, taking into account probable success and failure of activities that require borrowing, the additional possibilities of value creation would emerge, and in turn, the possibilities to gain additional benefit for the creditor as well as for the debtor. Practically such possibilities are considered in all particular borrowing cases, but the unique theoretical viewpoint on debt management should still be formed.

\subsection{Is borrowing a self-regulating process?}

There has never been any doubt that the proper amount of borrowing stimulates economic growth, and also can become a condition of wealth growth. But many papers on highly developed economies referring to statistical data and other theoretical tests (Cecchetti et al. 2011) predicate the thresholds amounting to 85 percent of GDP to household and government debt and 90 percent of GDP to national business, the overstepping of which with debt growth becomes dangerous for economic growth rate. Also, it has been confirmed, that these thresholds should be precisely measured. It is stated that if debt oversteps the mentioned thresholds, other conditions remaining the same, the economy growth rates decrease.

Debt management strategy, which was based on facts requiring the broader viewpoint, states that one shouldn't overdraft the a priori established debt growth norms. The necessity of such viewpoint is also discussed in debt management strategy (Public Sector Debt Statistics 2011) proposed by the IMF (International Monetary Fund).

\section{The methodology for formulation of tasks on general debt management optimization and their solution}

In this chapter, the authors will recall the promise already declared in the abstract of the paper - to present the government debt optimal management possibility, based on the maximization of the present value of the difference between the effect generated from the debt obtained in a particular year (hereinafter $-t$ year) and costs generated by debt servicing.

Section 4.1 describes the logics behind the determination of the present value of debt servicing costs and possible effect of the present value of debt use, which are depicted in Schemes 1 and 2, respectively.

In turn, it is worth noticing that seeking for the adequate effect of debt use as well as debt servicing cost evaluation, it is necessary to invoke the stochastic assessment ideology and technique. It is clear that analyzing the possible effects of debt use the avoidance of the recognition of stochastic nature of these processes would be unacceptable. 
This remark equally concerns the debt servicing costs, when the interest on borrowed funds is often linked with stochastically changing global financial parameters and also when the violation of debt conditions traditionally changes the parameters of costs. Besides, the lack or absence of statistical observations, data and etc. is often observed in the attempts to reveal the possible stochastic consistent patterns in debt management problems. The expert evaluation based on the informative expert assessment principles will be used while analyzing particular situations in the paper.

\subsection{Formulation of an optimization task}

The projected government debt volume $S^{t}$ for t-years must be composed (see Scheme 1) of borrowing volumes according to every borrowing tool $S_{1}^{t}, S_{2}^{t}, \ldots, S_{I}^{t}$ such as $\sum_{i=1}^{I} S_{i}^{t}=S^{t}$ and debt must be used (see Scheme 2) for investment in K public activity sectors $V_{1}^{t}, V_{2}^{t}, \ldots, V_{K}^{t}$ such that $\sum_{k=1}^{K} V_{k}^{t}=V^{t}=S^{t}$. Unfortunately, the determined comparison possibilities of the borrowed and used sum ends here, because cost of debt service formation as well as investment efficiency achievement in various public activity sectors evidences that described processes, their relationships and interactions are characterized by stochastic nature. On the other hand, the systems of developed stochastic process analysis and management allow expecting success during public debt management analysis performed using multicriteria stochastic optimization and also checking the emerging sustainability conception.

Thus, the emerging debt service costs as well as the resulting effects of investment of borrowed funds can be identified with the help of specialized stochastic models. It can be stated that using historical data, simulation options and expert assessments, one can create uncontroversial system of stochastic models, allowing to form the positive and practically-confirmed stochastic optimization criteria and debt management system.

The adequacy and consistency of the system is guaranteed by the fact that at this stage the focus is not on the problem related to formation of strategic principles for public debt management, but simply on the marginal optimization problem, attempting to determine the ways to optimize additional conditional net effect, i.e. to maximize the benefit of the difference between the generated benefit and incurred costs for borrowed marginal relative unit for each analysed country.

The sequence of formation of Schemes 1 and 2 is fully explained at the beginning of the chapter. However, it can be repeated that the present value $P V\left(S^{t}\right)$ of the servicing costs $S^{t}$ of the debt obtained in $t$ year becomes a stochastic value due to the uncertainty of discount rate in the time interval $\left[t, t+\tau^{-}\right]$, as well as because of a possibly real ambiguity of the interest rate for the same period. In this step, the selection of the adequate stochastic dependencies in Schemes 1 and 2 was performed using the method of stochastically informed expertise (Rutkauskas 2012b).

Further (Scheme 2), completely analogically to the present value of the cash flow generated by debt servicing, the present value created by the use of debt obtained in the year $t$ will be presented. While debt servicing of the year $t$ went into the time interval $\left[t, t+\tau^{-}\right]$, the obtained effect is evaluated in the interval $\left[t, t+\tau^{+}\right]$. 
Scheme 1. Digest on the formation of servicing components and their present values pertaining to the debt obtained in the year $t$, or the formation logics of the present value $P\left(S^{t}\right)$ of debt servicing

\begin{tabular}{|c|c|c|c|c|}
\hline \multicolumn{5}{|c|}{ Debt extent of the year $t$} \\
\hline Years & \multicolumn{3}{|c|}{ Debt extent according to every debt tool } & Total \\
\hline$t$ & $S_{1}^{t}$ & $S_{2}^{t}$ & $S_{I}^{t}$ & $\sum_{i=1}^{I} S_{i}^{t}=S^{t}$ \\
\hline \multicolumn{5}{|c|}{$t$ year's debt service extent of the year $t$ to the year $t+\tau^{+}$} \\
\hline$t$ & $S_{1}^{t+0}$ & $S_{2}^{t+0}$ & $S_{I}^{t+0}$ & $\sum_{i=1}^{I} S_{i}^{t+0}=S^{t+0}$ \\
\hline$t+1$ & $S_{1}^{t+1}$ & $S_{2}^{t+1}$ & $S_{I}^{t+1}$ & $\sum_{i=1}^{I} S_{i}^{t}=S^{t+1}$ \\
\hline \multicolumn{5}{|c|}{ 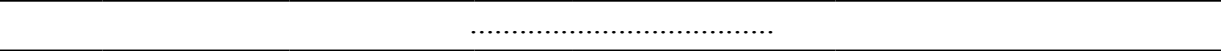 } \\
\hline$t+\tau^{-}$ & $S_{1}^{t+\tau-}$ & $S_{2}^{t+\tau-}$ & $\ldots \quad S_{I}^{t+\tau-}$ & $\sum_{i=1}^{\tau} S_{i}^{t+\tau^{-}}=S^{t+\tau-}$ \\
\hline \multicolumn{5}{|c|}{ Present values of the debt service extent of the year $t$} \\
\hline$t+\tau^{-}$ & $P V\left(S_{1}^{t+\tau-}\right)$ & $P V\left(S_{2}^{t+\tau-}\right)$ & $P V\left(S_{I}^{t+\tau^{-}}\right)$ & $\sum_{i=1}^{I} P V\left(S_{i}^{t+\tau^{-}}\right)=P V\left(S^{t+\tau-}\right)$ \\
\hline$\cdot$ & $\cdot$ & $\cdot$ & $\cdots$ & $\cdot$ \\
\hline$\cdot$ & $\cdot$ & $\cdot$ & $\cdots$ & · \\
\hline$t+1$ & $P V\left(S_{1}^{t+1}\right)$ & $P V\left(S_{2}^{t+1}\right)$ & $P V\left(S_{I}^{t+1}\right)$ & $\sum_{i=1}^{I} P V\left(S_{i}^{t+1}\right)=P V\left(S^{t+1}\right)$ \\
\hline$t+0$ & $P V\left(S_{1}^{t+0}\right)$ & $P V\left(S_{2}^{t+0}\right)$ & $\cdots \quad P V\left(S_{1}^{t+\tau^{+}}\right)$ & $\sum_{i=1}^{I} P V\left(S_{i}^{t+0}\right)=P V\left(S^{t+0}\right)$ \\
\hline \multicolumn{5}{|c|}{ The total present value of debt service payments of years $t$} \\
\hline \multicolumn{4}{|c|}{$P V\left(\sum_{\tau=0}^{\tau-} V_{i}^{t+\tau}\right)=P V\left(S_{i}^{t}\right), i=1,2, \ldots, I$} & $\sum_{\tau=1}^{\tau^{-}} P V\left(S_{i}^{t}\right)=P V\left(S^{t}\right)$ \\
\hline
\end{tabular}

Probably, explanation of the Scheme 2 does not need arguing that turning of debt $S^{t}$ into the present value $P V\left(V^{t}\right)$ of the created effect requires the description of the investigated processes with regard to uncertainty. Of course, it is the practical problem of high complexity, seeking to obtain the adequate solution for the raised problem. The existing methods of stochastically informed expertise (Rutkauskas 2012b), the techniques of stochastic optimization as well as the methods of stochastic evaluation of losses incurred by the environmental or social components, allow expecting for the success. 
Scheme 2. Public debt utilization and the created present value of the year $t$

\begin{tabular}{|c|c|c|c|c|c|}
\hline \multicolumn{6}{|c|}{ Public debt utilization of the year $t$} \\
\hline \multicolumn{6}{|c|}{ Utilization according to public sectors } \\
\hline & 1 & 2 & $\ldots$ & $k$ & Total \\
\hline$t$ & $V_{1}^{t}$ & $V_{2}^{t}$ & $\cdots$ & $V_{k}^{t}$ & $V^{t}=\sum_{k=1}^{K} V_{k}^{t}=\sum_{i=1}^{I} S_{i}^{t}=S^{t}$ \\
\hline \multicolumn{6}{|c|}{ The effect of the debt for the year $t$ used in the public sector } \\
\hline$t$ & $V_{1}^{t+0}$ & $V_{2}^{t+0}$ & $\cdots$ & $V_{k}^{t+0}$ & $\sum_{k=1}^{K} V_{k}^{t+0}=V^{t+0}$ \\
\hline$t+1$ & $V_{1}^{t+1}$ & $V_{2}^{t+1}$ & $\cdots$ & $V_{k}^{t+1}$ & $\sum_{k=1}^{K} V_{k}^{t+1}=V^{t+1}$ \\
\hline$t+\tau^{+}$ & $V_{1}^{t+\tau+}$ & $V_{2}^{t+\tau+}$ & $\cdots$ & $V_{k}^{t+\tau+}$ & $\sum_{k=1}^{K} V_{k}^{t+\tau+}=V^{t+\tau+}$ \\
\hline \multicolumn{6}{|c|}{ The present values of effects of funds borrowed in the year $t$} \\
\hline$t+\tau^{-}$ & $P V\left(V_{1}^{t+\tau+}\right)$ & $P V\left(V_{2}^{t+\tau+}\right)$ & $\cdots$ & $P V\left(V_{k}^{t+\tau+}\right)$ & $\sum_{k=1}^{K} P V\left(V_{k}^{t+\tau+}\right)=P V^{t+\tau+}$ \\
\hline$\cdot$ & $\cdot$ & $\cdot$ & $\cdots$ & $\cdot$ & $\cdot$ \\
\hline$\cdot$ & $\cdot$ & $\cdot$ & $\cdots$ & $\cdot$ & $\cdot$ \\
\hline$\cdot$ & $\cdot$ & $\cdot$ & $\cdots$ & $\cdot$ & $\cdot$ \\
\hline$t+1$ & $P V\left(V_{1}^{t+1}\right)$ & $P V\left(V_{2}^{t+1}\right)$ & $\cdots$ & $P V\left(V_{k}^{t+1}\right)$ & $\sum_{k=1}^{K} P V\left(V_{k}^{t+1}\right)=P V^{t+1}$ \\
\hline$t+0$ & $P V\left(V_{1}^{t+0}\right)$ & $P V\left(V_{2}^{t+0}\right)$ & $\ldots$ & $P V\left(V_{k}^{t+0}\right)$ & $\sum_{k=1}^{K} P V\left(V_{k}^{t+0}\right)=P V^{t+0}$ \\
\hline \multicolumn{6}{|c|}{ The total present value of debt effects generated by the debt of the year $t$} \\
\hline$t$ & & $\left.{ }_{k}^{t+\tau}\right)=P V(l$ & & $\ldots, K$ & $\sum_{k=1}^{K} P V\left(V_{K}\right)=P V\left(V^{t}\right)$ \\
\hline
\end{tabular}

\subsection{Applied optimization criteria}

It is necessary to choose a combination of borrowing tools and investments into specific activities. This combination should give the maximum of utility function $U$ :

$$
U(n p v(e f), P\{\zeta>n p v(e f)\}, \operatorname{rnpv}(e f)\})=\frac{n p v(e f) \times P\{\xi>n p v(e f)\}}{\operatorname{rnpv}(e f)}=>\max \text {. }
$$

Here: $n p v(e f)$ - the present value of effect possibilities generated by the debt; $P\{\zeta>n p v(e f)\}$ - the guarantee for the possibility of the present value; $r n p v(e f)-$ the riskiness of the possibility.

Detailed description of solution possibilities of the formulated problem is presented in the next chapter. 


\section{The essence of adequate portfolio model and its suitability for the formation of government debt-related integral asset and liability portfolio}

\subsection{The scheme for formation and use of an adequate portfolio}

The concept of portfolio is used in various fields of research and practical activity. This concept is used in various perceptions even in fields of investment and finance. The traditional case of investment portfolio perception as a set of homogeneous securities that belongs to one subject equals the sum of respective number's random variables, and it is being substituted with a set of non-homogeneous securities that belong to one subject. The variety of relations among changing securities becomes especially complex. Merely the entirety of non-homogeneous securities in the portfolio can create a hardly solved chain of interactions. Thus, it is hardly a surprise that the technique used for portfolio management is getting complex continuously and quickly. A portfolio becomes an especially important instrument of systemic analysis, which according to its nature is intended for solving the complex stochastic systems, and, what is especially important, for optimal allocation of resources among the subsystems interacting under conditions of uncertainty.

The detailed information about the adequate portfolio and its application possibilities can be found in publications by authors (Rutkauskas, Stasytytė 2011; Rutkauskas 2012a).

In this paper, the portfolio will be perceived as an integral portfolio of assets created due to the funds borrowed by the government and liabilities emerged in relation to that borrowing. It is clear that to achieve the integral effect of borrowing and debt management one should invoke the technique adequate for informative supply of decisions and search for solutions.

In the presented experiment, the possibilities of adequate portfolio (Rutkauskas 2006) the portfolio adequate for the stochastic nature of investment assets - will be used. This will allow evaluating borrowing and the use of the received debt according to its efficiency as well as reliability. Traditionally, the portfolio will be presented as means of asset and liability management.

\subsection{The anatomy of the adequate portfolio}

In order to reveal the contents and possibilities of the adequate portfolio, it should be treated as natural follow-up of the modern or Markowitz portfolio.

Simplifying the Markowitz portfolio, it can be interpreted as follows: having $n$ investment assets $A_{1}, A_{2}, \ldots, A_{n}$, that form a property of a subject and generate income for this subject, expressed in random values $a_{1}\left(\alpha_{1}, \sigma_{1}\right), a_{2}\left(\alpha_{2}, \sigma_{2}\right), \ldots, a_{n}\left(\alpha_{n}, \sigma_{n}\right)$. Here, $\alpha_{i}, \sigma_{i}$ are respectively the mean value $\alpha_{i}$ of the random value $a_{i}$ and standard deviation $\sigma_{i}$ of the random value $a_{i}$. A subject can evaluate how one should distribute the capital intended for investment among the separate assets, i.e. how one should choose the proportions $w_{1}, w_{2}, w_{3}, \ldots, w_{n}\left(\sum_{i=1}^{n} w_{i}=1\right)$, according to which the whole capital is allocated 
among the assets. For simplified perception, it is possible to say that there is a great unit of money (ex., 1 million) and thus $w_{i}$ will describe the parts of this unit. In order to determine the best diversification possibilities of investment capital, it is worth analysing the distribution of all the possibilities of the possessed capital among the assets:

$$
\begin{gathered}
w_{1}^{1} a_{1}+w_{2}^{1} a_{2}+\ldots+w_{n}^{1} a_{n}=S^{1} \\
w_{1}^{2} a_{1}+w_{2}^{2} a_{2}+\ldots+w_{n}^{2} a_{n}=S^{2} \\
\ldots \\
w_{1}^{m} a_{1}+w_{2}^{m} a_{2}+\ldots+w_{n}^{m} a_{n}=S^{m} .
\end{gathered}
$$

To find the best variant of investment capital diversification, one needs just to revise all the possibilities of structural allocation, i.e. to demand that structural complexes $\left\{w_{i}^{j}\right\}, i=1,2, \ldots, n ; j=1,2, \ldots, m$ would in reality reflect all the possibilities of capital allocation among the selected investment assets. Practically, the evaluation of capital possibilities is performed using the following calculations:

$$
\left\{\begin{array}{c}
w_{1}^{1} a_{1}+w_{2}^{1} a_{2}+\ldots+w_{n}^{1} a_{n}=S^{1} \\
w_{1}^{2} a_{1}+w_{2}^{2} a_{2}+\ldots+w_{n}^{2} a_{n}=S^{2} \\
\ldots \\
w_{1}^{m} a_{1}+w_{2}^{m} a_{2}+\ldots+w_{n}^{m} a_{n}=S^{m},
\end{array}\right.
$$

here $\left(\sum_{i=1}^{n} w_{i}^{j}=1\right)$ for every $j=1,2, \ldots, m$.

$S^{j}, j=1,2, \ldots, m$ - are the values of differently diversified portfolios, obtained as functions of assets and allocation coefficients. These values are stochastic variables with their parameters - mean value, standard deviation, variation, quartiles, deciles and other quintiles, etc., which, in turn, depend on the probability distributions of asset possibilities and their interdependencies.

In graphical analysis the sets of possible values of a portfolio are usually analysed. In the case with the Markowitz portfolio, the obtained system (3) is analysed, where every value of a set of values $\left\{S^{j}\right\}$ of the portfolio is described by its mean value and standard deviation.

Graphically, this situation is presented in Figures 1a and 1b. In Figure 1a all of the possible values are depicted, while in Figure $1 \mathrm{~b}$ - only the efficient values, i.e. those that have maximum mean values for the selected standard deviation level.

The standard deviation-mean analysis and decision-making methodology plays an especially important role in recognizing and quantifying the investment possibilities as stochastic values or processes.

However, analysts as well as practitioners are actually interested not only in mean values of portfolio possibilities, but also in constructive characteristics of various situations such as median, mode, various quintiles, etc., or simply in the probability distribution of every $S^{j}$. The primary objective of the adequate portfolio is to form the so-called efficient surface, analogous to the efficient frontier in the modern portfolio case. For 
a)

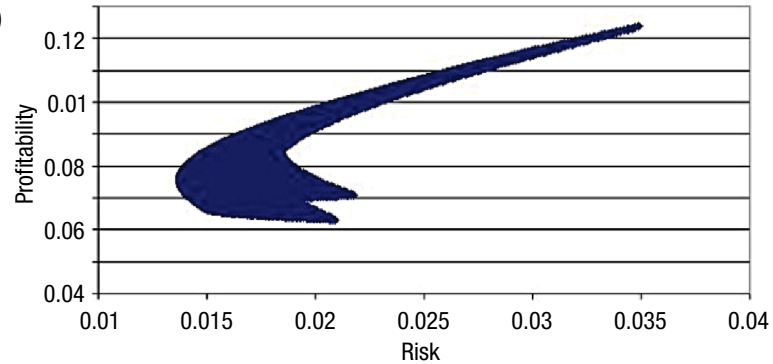

b)

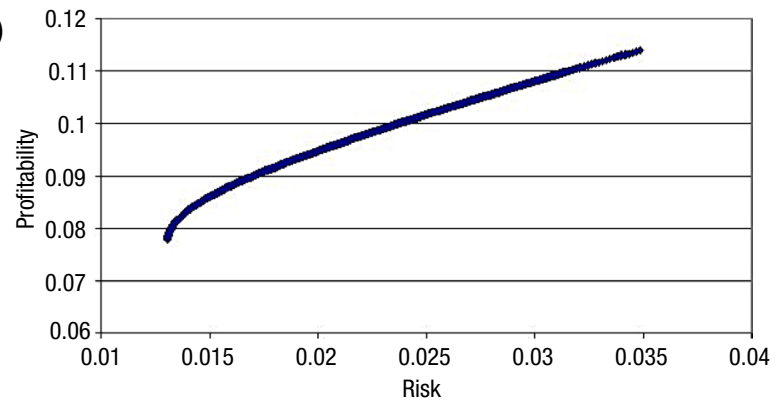

c)

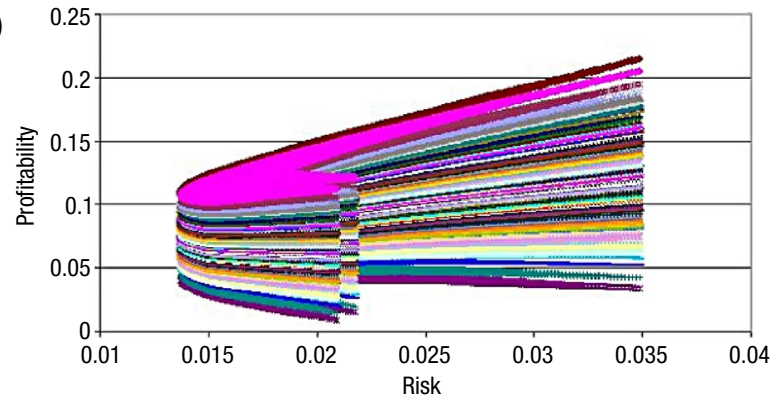

d)

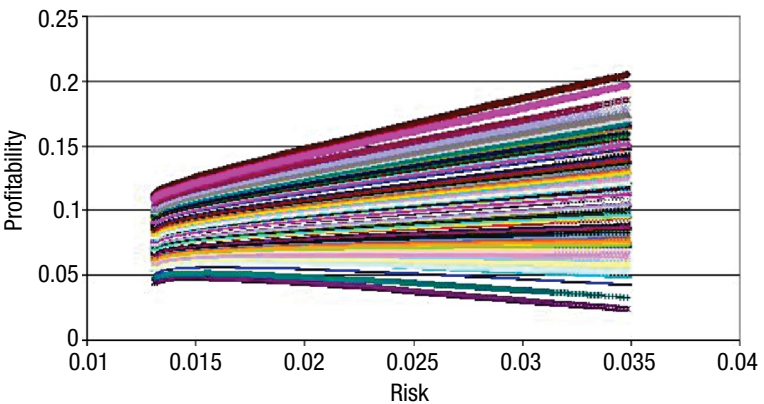

Fig. 1. Initial steps of transition from Markowitz to adequate portfolio:

a) the set of values of the Markowitz or "mean-standard deviation" portfolio;

b) the set of values of the efficient frontier of "mean-standard deviation" portfolio;

c) the set of values of the "percentiles-standard deviation" portfolio;

d) the efficient frontiers of the bunch of "quintiles-standard deviations" portfolios 
this purpose, the "standard deviation-percentiles" (virtually there can be any quintiles) bunch of portfolios, or the set of possible values is formed (Fig. 1c), along with the respective bunch of efficiency lines (Fig. 1d). Every selected point $\xi_{p}$ on "standard deviation-the percentile of $p$ level" efficient frontier possesses the following characteristic (probability):

$$
P\left\{\xi>\xi_{p}\right\}=p, p=0 ; 0,01 ; 0,02 ; \ldots, 1 .
$$

This circumstance indicates that if percentile efficient frontiers are raised to the level of respective percentile's value on the applicate axis, then an efficient surface appears with analogous characteristics as efficient frontier in the plane "standard deviation-mean value" (Fig. 2b).

However, for convenience of presentation, the bunch of efficient frontiers presented in Figure 1d should be rotated in order to put it in the first quadrant of the plane $(\sigma, p)$. If in Figures $2 a$ and $2 b$ the schematic views are presented, then in Figure 3 the surfaces of real calculations are depicted, when assets were assumed to be three Normal probability distributions $\mathrm{N}_{1}\left(\alpha_{1}=0,062 ; \sigma_{1}=0,022\right) ; \mathrm{N}_{2}\left(\alpha_{2}=0,07 ; \sigma_{2}=0,023\right)$; $\mathrm{N}_{3}\left(\alpha_{3}=0,13 ; \sigma_{3}=0,03\right)$.
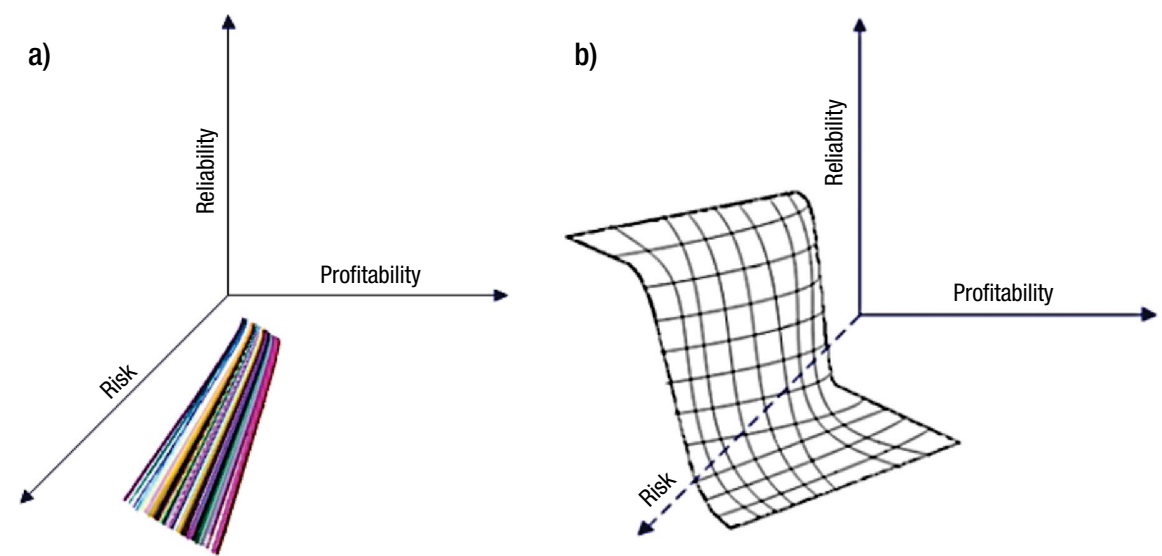

Fig. 2. Schematic view of efficient surface formation: a) rotation of efficient frontiers; b) raising of efficient frontiers

\subsection{Formation of the utility function for the adequate portfolio}

In order to disclose the commensuration process of profitability, risk and reliability in more details while forming utility function, first of all, it is advisable to present the expressions of utility function in two two-dimensional planes: profitability-risk and profitability-reliability. The detailed analysis of such functions is presented by Rutkauskas (2006, 2012a), Rutkauskas, Stasytytė (2010).

After investigating the versions of utility function in profitability-reliability and profitability-risk planes, it must be analysed how the combination of these functions into 


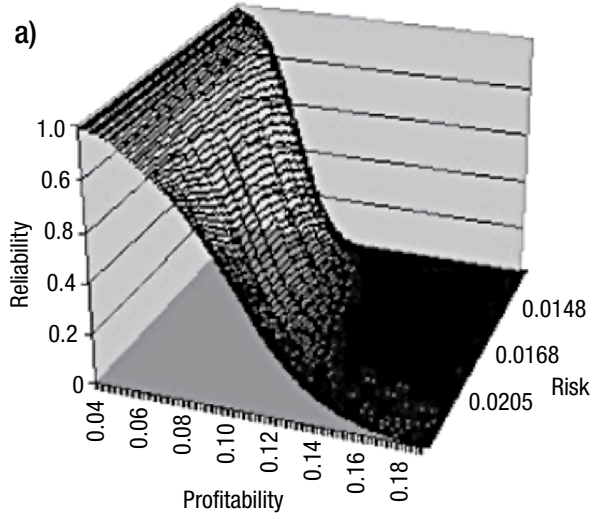

b)

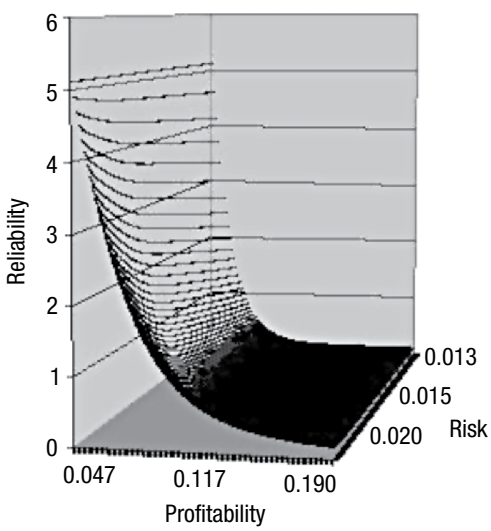

Fig. 3. The possibility surface of adequate portfolio and investor utility function (Rutkauskas, Stasytyte 2011): a) efficient surface (geometrical view) of the adequate portfolio;

b) the view of the utility function

a single network could produce a three-dimensional utility function, described by the profitability of the general possibility of a portfolio, the reliability of that possibility and the risk faced by investor in case the possibility happens. For this reason a threeparametric utility function in profitability-risk-reliability space is constructed (Fig. 4). The composed utility function, approaching the set of values of the adequate portfolio, indicates the portfolio value with the highest utility, and, in turn, the portfolio itself. It is worth noticing that if the set of possibilities of adequate portfolio is an intersection network of survival functions and izoguarantees, then spatial utility function is a network of intersection of profitability-risk and profitability-guarantee utility functions. Graphical view of such a utility function is formed using analytical expression:

$$
U=\exp \left(\frac{e}{r}\right) \cdot g,
$$

here: $U$ - utility level of possibility; $e$ - profitability; $r$ - risk; $g$ - guarantee.

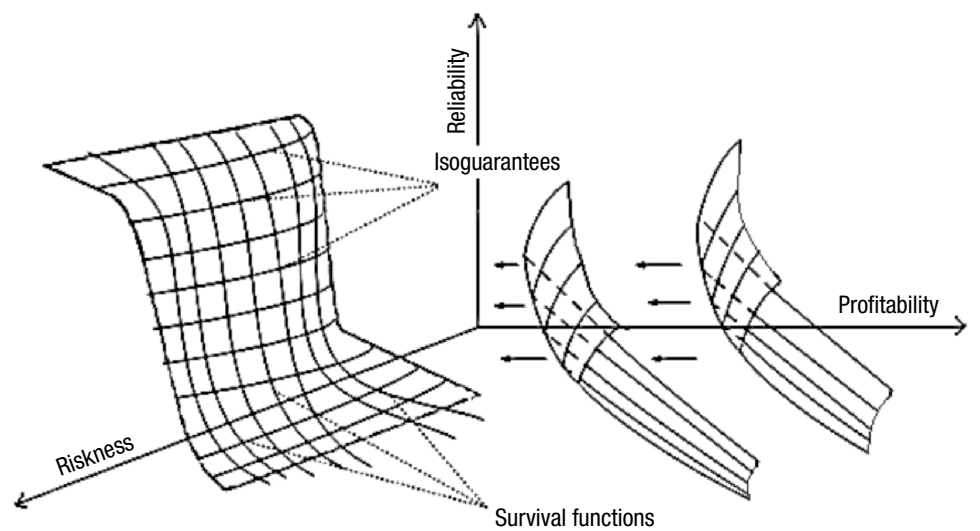

Fig. 4. Utility surface approaching the surface of possibilities (Rutkauskas 2006) 
Such specification of utility function and decision-making procedure is analytically meaningful because in such a manner the complex stochastic programming problem is being solved using imitative technologies and graphical decision-making means.

Consequently, the logics of the adequate portfolio formation, which serves as the base for the analysis of guarantee of every profit possibility, being described as a probability that the profitability (return) on investment will not be lower than the certain level, presents the full disclosure of the interaction of guarantee of profitability and risk, as a measure for interaction of variability pertaining to profit possibilities with utility function of an investor.

\section{Expert formation and solutions of adequate portfolio of government debt generated liabilities and assets}

\subsection{Prerequisites for formation of optimized portfolio}

In scientific literature, M. Melecky (2012) attempts to reveal how the government debt portfolio should be formed in order to minimize the cost of debt. It is clear that minimization should be adequately perceived. In government debt strategy formation, the evaluation of reliability pertaining to cost of debt possibilities cannot be avoided. Of course, the volume of cost of debt possibilities and the reliability of these possibilities should be commensurated. Thus, the content of adequate investment portfolio is oriented towards such decision while developing the government debt portfolio (Rutkauskas 2006).

As it was stated at the beginning of the paper, along with debt liabilities, the debt-generated assets will be analysed as certain processes that generate certain values using government debt funds by developing these values or ensuring possibilities to avoid losses, i.e. allowing to retain the possessed possibilities. Loss avoidance using investment or operating assets is a broadly used concept in environmental protection, as well as in life and non-life insurance or in any other activities. The funds borrowed by the government are usually used to ensure the quality of the core functions of the government.

However, the evaluation of loss or damage derived from the insufficient quality of the most often discussed government functions - defence, education, transportation, public health, social security, legal and judicial functions - is not a simple solution of the problem, especially when the functions should be evaluated. Taking into account that such evaluations are almost not collected and there are no such statistics, the expert valuations should be applied.

In the research, the functions that are usually performed using budget financing in Lithuania were divided into three groups:

The first group - education and science, economics, business promotion, agriculture;

The second group - social security, health, public order and security of the society;

The third group - environmental protection, defence, culture, religion, leisure.

According to the opinion of specialists of these activities, only the first group can be currently purposefully credited with the evaluated effect that can be determined by the 
marginal financing volume of the government debt. The second, as well as the third group can responsibly operate the categories of avoidable loss or damage that can be revealed under shortage of financing. According to the special projects prepared for every group an internal group structure is already fixed and efficiency indicators determined $-a_{1}\left(\alpha_{1}, s_{1}\right), a_{2}\left(\alpha_{2}, s_{2}\right)$ and $a_{3}\left(\alpha_{3}, s_{3}\right)$. These are stochastic values showing the generalized effect of marginal investment unit on the entire group, where $\alpha_{i}, s_{i}, i=1$, 2, 3 are the mean values and standard deviations of the effect.

In 2011-2012 in Lithuania, the government securities were the main debt instruments together with loans and deposits. The possessed information about debt instruments in many countries for a long time allows to reasonably enough determine the indicators of debt servicing of borrowed marginal unit according to every debt instrument. As well as in the case of assets, the fixed structure of the used instruments in every mentioned group of three instruments, and the indicators of debt servicing of the borrowed marginal unit were formulated $-l_{1}\left(\beta_{1}, \delta_{1}\right), l_{2}\left(\beta_{2}, \delta_{2}\right), l_{3}\left(\beta_{3}, \delta_{3}\right)$. Debt servicing indicators were also projected as random values, where $\beta_{i}, \delta_{i}$ are their mean values and standard deviations.

Expert valuations were performed using stochastically informed expertise method (Rutkauskas 2012b).

\subsection{Optimization of the government debt generated integral asset and liability portfolio}

The idea of optimization - to select such borrowing proportions $\omega_{1}^{l}, \omega_{2}^{l}, \omega_{3}^{l}$ $\left(\omega_{1}^{l}+\omega_{2}^{l}+\omega_{3}^{l}=1\right)$ and such proportions of borrowed funds distribution among the assets $-\omega_{1}^{a}, \omega_{2}^{a}, \omega_{3}^{a}\left(\omega_{1}^{a}+\omega_{2}^{a}+\omega_{3}^{a}=1\right)$ that the present value $N P V\left(D_{t}\right)$ of the debt $D_{t}$ for the analysed year is the maximum measured according to the adequate utility function, i.e. according to the function in which the effect and reliability of possibilities is taken into account.

With the help of the possessed data and stochastically informed expertise (Rutkauskas $2012 \mathrm{~b}$ ), the following values of $\mathrm{a}_{i}$ and $\mathrm{l}_{i}$ indicators were selected:

$a_{1}\left(\alpha_{1}, s_{1}\right)$, here $\alpha_{1}=1,461 ; \sigma_{1}=0,012$,

$a_{2}\left(\alpha_{2}, s_{2}\right)$, here $\alpha_{1}=1,320 ; \sigma_{1}=0,044$,

$a_{3}\left(\alpha_{3}, s_{3}\right)$, here $\alpha_{1}=1,061 ; \sigma_{1}=0,045$,

$l_{1}\left(\beta_{1}, \delta_{1}\right)$, here $\beta_{1}=1,546 ; \quad \delta_{1}=0,170$,

$l_{2}\left(\beta_{2}, \delta_{2}\right)$, here $\beta_{1}=1,202 ; \quad \delta_{1}=0,058$,

$l_{3}\left(\beta_{3}, \delta_{3}\right)$, here $\beta_{1}=1,019 ; \quad \delta_{1}=0,007$.

Here $\alpha_{i}$ and $\beta_{i}$ are the mean values of random variables, $\sigma_{i}$ and $\delta_{i}-$ standard deviations. In the particular case, the utility function was selected as follows:

$$
U=\exp \left\{\frac{n \times p}{r}\right\},
$$

here $n$ - possibility, $p$ - the reliability of possibility $n, r$ - the risk, $U$ - utility. 
In Figure 5, the anatomy of decision search is presented: a - the general view of possibilities, $\mathrm{b}$ - the utility function, $\mathrm{c}-$ the general view of the set of possibilities and utility function, $\mathrm{d}$ - determining the particular possibility, $\mathrm{e}-$ the particular solution.

a)

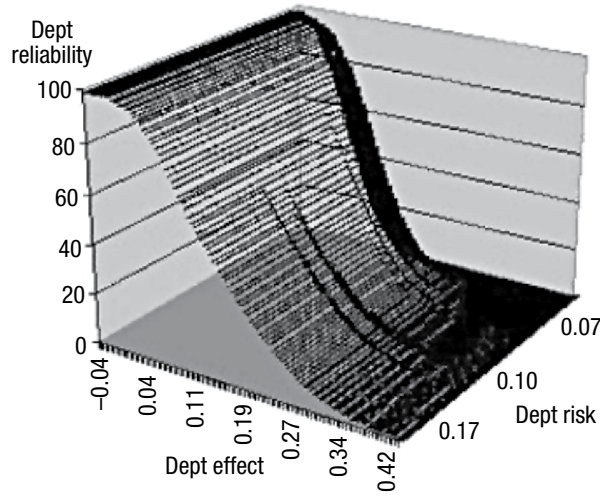

c) Dept

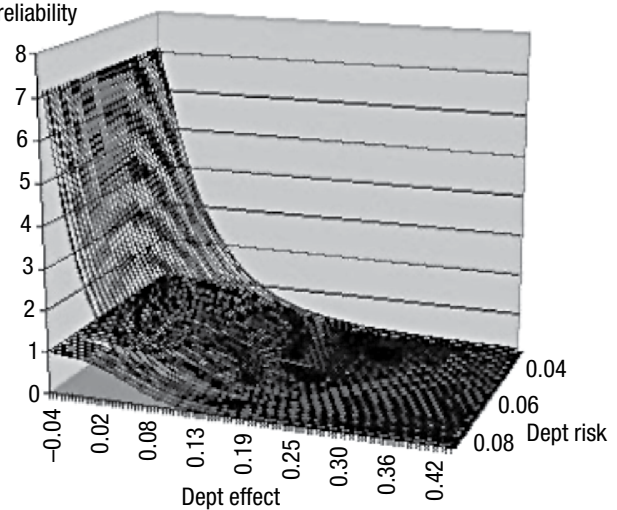

b)

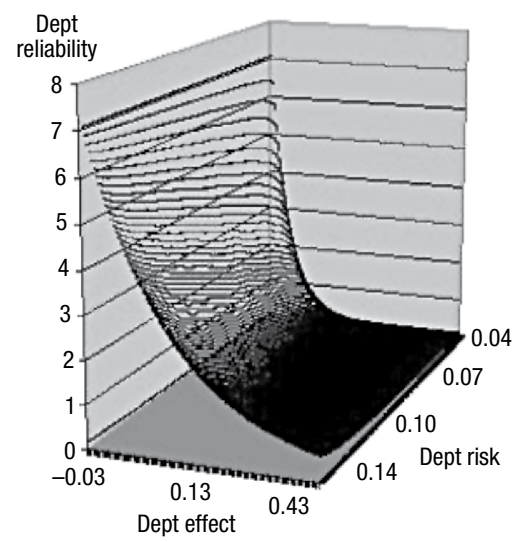

d)

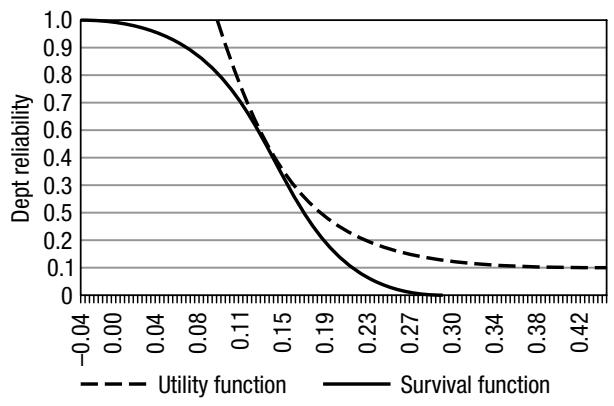

e)

\begin{tabular}{|c|c|c|c|c|c|}
\hline \multicolumn{3}{|c|}{ The invesment (use of debt) structure } & \multicolumn{3}{|c|}{ Borroving structure } \\
\hline$\omega_{1}^{a}-0.685$ & $\omega_{2}^{a}-0.305$ & $\omega_{3}^{a}-0.01$ & $\omega_{1}^{l}-0.05$ & $\omega_{2}^{l}-0.685$ & $\omega_{3}^{l}-265$ \\
\hline \multicolumn{6}{|c|}{ Parameters of optimal solution } \\
\hline \multicolumn{2}{|c|}{ The effect of debt use - profitability } & \multicolumn{2}{|c|}{ Effect reliability } & \multicolumn{2}{|c|}{ Risk level of effect } \\
\hline \multicolumn{2}{|c|}{0.127} & \multicolumn{2}{|c|}{0.549} & \multicolumn{2}{|c|}{0.061} \\
\hline
\end{tabular}

Fig. 5. The anatomy of decision search: a) three-dimensional surface; b) utility function; c) possibility surface and utility function - three-dimensional view; d) possibility surface and utility function - the tangency point; e) the information about optimal solution 


\section{Conclusions}

1. The management of government borrowing process usually does not cover all moments of use of the received debt. While fostering the government debt management strategies, probably the most important problem is the efficient use of the borrowed funds, at the same time seeking the optimization of the borrowing effect itself.

2. Borrowing and debt utilization processes are linked by the common objective - to obtain the highest gross debt utilization effect, along with the set of impacts on financial system, raised by the time and risk. Thus, integrated borrowing and debt utilization management has clear advantages.

3. In analytical research works, there are no more or less universal or thorough methodology on quantitative evaluation of losses incurred by the society, environmental protection or business, if the objective resources do not reach the required standards or norms. At least expert systems must be oriented towards the solution of such problems.

4. Orientation towards the optimization of annual government debt effect gross present value should become the core attitude while formulating strategic provisions pertaining to the government debt management.

5. Borrowing expenses and preconceived (projected) evaluations of debt management must be named according to their extent and reliability.

\section{Acknowledgements}

The research was financed by The Research Council of Lithuania (IEP-01/2012).

\section{Refereces}

Afonso, A.; Jalles, J. T. 2013. Growth and productivity: the role of government debt, International Review of Economics and Finance 25: 384-407. http://dx.doi.org/10.1016/j.iref.2012.07.004

Asici, A. A. 2013. Economic growth and its impact on environment: a panel data analysis, Ecological Indicators 24(January): 324-333. http://dx.doi.org/10.1016/j.ecolind.2012.06.019

Balibek, E.; Koksalan, M. 2010. A multi-objective multi-period stochastic programming model for public debt management, European Journal of Operational Research 205(1): 205-217.

http://dx.doi.org/doi:10.1016/j.ejor.2009.12.001

Bartolomeo, G. D.; Giuli, F. 2011. Fiscal and monetary interaction under monetary policy uncertainty, European Journal of Political Economy 27(2): 369-375.

http://dx.doi.org/10.1016/j.ejpoleco.2010.11.001

Bradley, M.; Chen, D. 2011. Corporate governance and the cost of debt: evidence from director limited liability and indemnification provisions, Journal of Corporate Finance 17(1): 83-107. http://dx.doi.org/doi:10.1016/j.jcorpfin.2010.08.001

Bruche, M.; Naqvi, H. 2010. A structural model of debt pricing with creditor-determined liquidation, Journal of Economic Dynamics \& Control 34(5): 951-967.

http://dx.doi.org/10.1016/j.jedc.2010.01.005

Bruneckiene, J.; Paltanaviciene, D. 2012. Measurement of export competitiveness of the Baltic States by Composite Index, Inzinerine Ekonomika - Engineering Economics 23(1): 50-62.

http://dx.doi.org/10.5755/j01.ee.23.1.1218

Canzoneri, M.; Cumby, R.; Diba, B. 2010. The interaction between monetary and fiscal policy, in Handbook of Monetary Economics 3: 935-999.

http://dx.doi.org/10.1016/B978-0-444-53454-5.00005-0 
Cecchetti, S. G.; Mohanty, M. S.; Zampolli, F. 2011. The real effects of debt, BIS Working papers No 352. 34 p. [online], [cited 15 November 2012]. Available from Internet: http://www.bis.org/ publ/othp16.pdf

Chen, D. 2012. Classified boards, the cost of debt, and firm performance, Journal of Banking \& Finance 36(12): 3346-3365. http://dx.doi.org/10.1016/j.jbankfin.2012.07.015

De Mendonca, H. F.; Machado, M. R. 2013. Public debt management and credibility: evidence from an emerging economy, Economic Modelling 30(January): 10-21.

http://dx.doi.org/10.1016/j.econmod.2012.09.009

De Santis, R.; Gerard, B. 2006. Financial integration, international portfolio choice and the European Monetary Union, Working paper 626, May [online], [cited 20 October 2012]. The European Central Bank. 52 p. Available from Internet: http://www.ecb.int/pub/pdf/scpwps/ecbwp626.pdf.

Drudi, F.; Giordano, R. 2000. Default risk and optimal debt management, Journal of Banking and Finance 24: 861-891.

Dubinskas, P.; Stungurienè, S. 2010. Alterations in the financial markets of the Baltic countries and Russia in the period of economic downturn, Technological and Economic Development of Economy 16(3): 502-515. http://dx.doi.org/10.3846/tede.2010.31

Kalyuzhnova, Y.; Nygaard, Ch. 2009. Resource nationalism and credit growth in FSU countries, Energy Policy 37(11): 4700-4710. http://dx.doi.org/doi:10.1016/j.enpol.2009.06.024

Landon, S.; Smith, C. E. 2007. Government debt spillovers in a monetary union, North American Journal of Economics and Finance 18(2): 135-154. http://dx.doi.org/10.1016/j.najef.2007.05.001

Lim, Y. 2011. Tax avoidance, cost of debt and shareholder activism: evidence from Korea, Journal of Banking \& Finance 35(2): 456-470. http://dx.doi.org/10.1016/j.jbankfin.2010.08.021

Martin, F. M. 2009. A positive theory of government debt, Review of Economic Dynamics 12(4): 608-631. http://dx.doi.org/10.1016/j.red.2009.02.003

Melecky, M. 2012. Formulation of public debt management strategies: an empirical study of possible drivers, Economic Systems 36(2): 218-234. http://dx.doi.org/10.1016/j.ecosys.2011.08.001

Mishkin, F. 2007. Is financial globalisation beneficial? Journal of Money, Credit and Banking 39(2-3): 259-294. http://dx.doi.org/10.1111/j.0022-2879.2007.00026.x

Mohd Daud, S. N.; Podivinsky, J. M. 2012. Revisiting the role of external debt in economic growth of developing countries, Journal of Business Economics and Management 13(5): 968993. http://dx.doi.org/10.3846/16111699.2012.701224

Muscatelli, V. A.; Tirelli, P.; Trecroci, C. 2004. Fiscal and monetary policy interactions: empirical evidence and optimal policy using a structural New-Keynesian model, Journal of Macroeconomics 26(2): 257-280. http://dx.doi.org/10.1016/j.jmacro.2003.11.014

Norvaisiene, R. 2012. The impact of capital structure on the performance efficiency of Baltic listed companies, Inzinerine Ekonomika - Engineering Economics 23(5): 505-516.

http://dx.doi.org/10.5755/j01.ee.23.5.1979

Pan, H.; Wang, Ch. 2012. Government debt in the euro area - evidence from dynamic factor analysis, Economic Letters 115(2): 272-275. http://dx.doi.org/10.1016/j.econlet.2011.12.084

Pekarskiene, I.; Susniene, R. 2011. An assessment of the level of globalization in the Baltic States, Inzinerine Ekonomika - Engineering Economics 22(1): 58-68.

http://dx.doi.org/10.5755/j01.ee.22.1.219

Pridotkiene, J.; Dapkus, M. 2011. The model to evaluate risk factors of exporter-provided trade credit, Inzinerine Ekonomika - Engineering Economics 22(5): 477-484.

http://dx.doi.org/10.5755/j01.ee.22.5.966

Public sector debt statistics. Guide for compilers and users. 2011. [Online], [cited 5 January 2013]. Washington: International Monetary Fund. 232 p. Available from Internet: http://www. tffs.org/pdf/method/PSDS11 fulltext.pdf 
Qin, D., et al. 2006. Empirical assessment of sustainability and feasibility of government debt: the Philippines case, Journal of Asian Economics 17(1): 63-84.

http://dx.doi.org/10.1016/j.asieco.2005.12.003

Rutkauskas, A. V. 2006. Adekvačiojo investavimo portfelio anatomija ir sprendimai panaudojant imitacines technologijas, Ekonomika: mokslo darbai 75: 52-76.

Rutkauskas, A. V.; Stasytytè, V. 2010. Effectiveness, reliability and subject risk - shaping drivers for the set of possibilities and utility function when investment decision is made under uncertainty, in The 6th International Scientific Conference "Business and Management - 2010", 13-14 May, 2010, Vilnius, Lithuania. Vilnius: Technika, 176-183.

http://dx.doi.org/10.3846/bm.2010.025

Rutkauskas, A. V.; Stasytyte, V. 2011. Optimal portfolio search using efficient surface and threedimensional utility function, Technological and Economic Development of Economy 17(2): 305326. http://dx.doi.org/10.3846/20294913.2011.580589

Rutkauskas, A. V. 2012a. Using sustainability engineering to gain universal sustainability efficiency, Sustainability 4(6): 1135-1153. http://dx.doi.org/10.3390/su4061135

Rutkauskas, A. V. 2012b. Stochastically informed expertise as natural step for experts systems network development, in Conference Proceedings of the $2^{\text {nd }}$ International Scientific Conference “Whither our Economies - 2012”, 15-16 October, 2012, Vilnius, Lithuania, 46-53.

Stulz, R. M. 2005. The limits of financial globalization, Journal of Finance 60(4): 1595-1638. http://dx.doi.org/10.1111/j.1540-6261.2005.00775.x

The Concise Encyclopedia of Economics: Friedrich August Hayek. Library of Economics and Liberty [online] [cited 6 January 2013]. Available from Internet: http://www.econlib.org/library/ Enc/bios/Hayek.html

Zhan, Y.; Zeng, X. 2012. Research on the robustness of debt financing strategy: a financial system engineering perspective, Systems Engineering Procedia 3: 172-178.

http://dx.doi.org/10.1016/j.sepro.2011.11.024

Žvirblis, A.; Buračas, A. 2010. The consolidated measurement of the financial markets development: the case of transitional economies, Technological and Economic Development of Economy 16(2): 266-279. http://dx.doi.org/10.3846/tede.2010.17

2013 metų nacionalinio biudžeto išlaidos pagal sritis [Expenses of government debt according to fields, 2013] [online], [cited 10 January 2013]. LR Finansų ministerija [Ministry of Finance]. Available from Internet: http://www.finmin.lt/web/finmin/2013_biudzetas/islaidos

Aleksandras Vytautas RUTKAUSKAS is a Professor and the Head of the Department of Finance Engineering at Vilnius Gediminas Technical University. His research interests are: investment portfolio management in capital and exchange markets, risk and uncertainty, sustainable development, integrated value and risk management

Viktorija STASYTYTÉ holds a PhD in Economics. She is an Associate Professor in the Department of Finance Engineering at Vilnius Gediminas Technical University. Her research interests are: capital markets, investment portfolio management, risk management, sustainable development.

Nijolė MAKNICKIENĖ holds a Master degree in Physics. She is a PhD student at the Department of Finance Engineering of Vilnius Gediminas Technical University. She is a Senior Manager at the Laboratory of Business Projection and Environmental Economics and an Assistant at the Department of Finance Engineering of Vilnius Gediminas Technical University. 